\title{
Determinants of Controlling in Foreign Subsidiaries of MNEs: On the Explanatory Potential of the Institutional Perspective
}

\author{
Cezary Kochalski, Magdalena Łuczak-Trąpczyńska
}

\begin{abstract}
A B S T R A C T
Objective: The main aim of this paper is to identify gaps in extant literature on controlling in MNEs, in particular factors affecting related managerial decisions. Secondly, the relevance of the institutional perspective will be examined for its potential to explain the design of controlling in foreign subsidiaries.

Research Design \& Methods: The dimensions of international controlling are discussed. Further, the institutional approach is examined for its applicability to advance the understanding of the determinants of shaping controlling systems in foreign subsidiaries of MNEs.
\end{abstract}

Findings: Institutional aspects can have a significant impact on the functioning of MNEs in relation to their controlling systems. Informal institutions can influence the formation of the controlling system in the relations between the subsidiaries of the MNE, whereby also institutions within the MNE itself should be taken into account.

Implications \& Recommendations: Conducting in-depth qualitative research will allow for a set of recommendations that are relevant to managers responsible for an effective implementation of management control systems.

Contribution \& Value Added: The relevance of the controlling system in parentsubsidiary relationships has not received significant attention in existing studies in the discipline of international controlling.

\begin{tabular}{ll}
\hline Article type: & conceptual/review paper \\
Keywords: & multinational enterprises (MNEs); controlling system; headquarters- \\
& subsidiary relationship; coordination, firm performance
\end{tabular}

JEL codes: $\quad$ F23, F65, L21, L22

Received: 2 April $2017 \quad$ Revised: 20 May $2017 \quad$ Accepted: 1 June 2017

Suggested citation:

Kochalski, C., \& Łuczak-Trąpczyńśka, M. (2017). Determinants of Controlling in Foreign Subsidiaries of MNEs: On the Explanatory Potential of the Institutional Perspective. Entrepreneurial Business and Economics Review, 5(3), 79-94. http://doi.org/10.15678/EBER.2017.050304 


\section{INTRODUCTION}

Establishing foreign subsidiaries and developing a multinational enterprise (MNE) outside of the country is one of the company's key business development strategies and has for years been a focal topic of interest in the disciplines of strategic management and international business (Verbeke, Li, \& Goerzen, 2009; Canabal \& White, 2008). The parent company's ownership and control over its subsidiaries located abroad is an immanent feature of MNEs (OECD, 2008; Vernon, Wells, \& Rangan, 1996). Although in the context of the aforementioned disciplines, such decisions as choosing the form of entry into a foreign market (e.g. acquisition or greenfield), the choice of the level of capital involvement and the ownership structure of the foreign company, or the choice of location for foreign operations have received predominant attention, the effective management of an MNE, which involves the coordination of international activities, is not less important (Kutschker \& Schmid, 2008).

From the perspective of strategic management of an international corporation, considerable attention has been paid to the implementation of a market strategy (with emphasis on marketing instruments), excluding issues related to control systems and factors significantly influencing their choice and, equally important, their effectiveness. The coordination of an MNE, by virtue of its complex organisational structure and its diverse business environments, is an additional challenge as compared to growth in the domestic market (Czinkota, Ronkainen, \& Moffett, 2005; Daniels \& Radebaugh, 2007; Holtbrügge \& Welge, 2010). Thereby, under coordination one can understand the mutual adaptation of elements of the international system to optimise it (Kutschker \& Schmid, 2008). Integration, harmonisation and unification of activities, tasks and decisions can be considered as the primary goal of this coordination process. In this context, the importance of controlling in MNEs is of particular importance (Brenner, 2009; Czyczerski, 2007, 2009; Gigouline, 2001; Hanzlick, 2014; Roth \& Nigh, 1992).

The main aim of this paper is to identify gaps in extant literature on controlling in MNEs, in particular factors affecting related managerial decisions. In the second step, the relevance of the institutional perspective will be examined for its potential to explain the design of the controlling system in foreign subsidiaries in order to create a model for the implementation of the controlling system in a subsidiary.

The paper is organised as follows. First of all, the concept and relevance of international controlling are explained. Subsequently, the dimensions of international controlling are discussed to enable a more detailed analysis of the concept and its determinants and to identify research gaps. Further, the institutional approach is introduced and discussed from the point of view of its applicability to bridge the stated research gaps and advance the understanding of the determinants of shaping controlling systems in foreign subsidiaries of MNEs. This discussion results in propositions for further research.

\section{LITERATURE REVIEW}

\section{The Concept and Relevance of International Controlling}

The essence of controlling is 'to build a logical system which, through structured combination of different structural elements of an enterprise, involved in economic, financial, organizational and technical activities, will help the managerial staff to make more relevant (credible) 
operational and strategic decisions' (Marciniak, 2008, p. 13). However, the concept of controlling has no uniform definition in international literature. Different schools around the world have different views, and numerous management scholars point to helplessness in trying to sort out this notion. In support of this statement, it can be recalled that Preissler (1999, p. 12) states that 'everyone has their own image of what controlling should be, but everyone thinks something else'. One of the reasons for the various explanations can be the ambiguity of the English notion of 'control'. For example, Nilsson (2002) assigns to the 'management control system' such constituents as the strategic planning and budgeting system, the performance measurement system, including the information on deviations from the budget, and other financial and non-financial information, capital expenditure procedures, and transfer pricing systems. The similarity of this approach to the understanding of the controlling system mentioned above accentuates the need to clarify the concepts in extant research.

Placing the concept of controlling in the context of international business operations has caused arguments that the main goal of the so called international controlling is to support the effective implementation of company goals by providing information bases for planning and control (Hahn \& Hungenberg, 2001; Horvath, 2009). The concept of controlling is often associated with a narrower concept of control (e.g. Nilsson, 2002; Granlund, 2003), which, according to Vollmuth (2000), is a simplistic approach, because controlling is in essence a management system. Control in MNEs involves planning, implementation, evaluation and revision of economic performance to ensure the achievement of goals by a complex and geographically dispersed whole (Daniels \& Radebaugh, 2007). Thus, in research on MNEs a considerable amount of attention has been paid to the control of foreign subsidiaries expressed by the parent's share of capital of a foreign subsidiary (see e.g. Beamish \& Lee, 2003; Gaur \& Lu, 2007; Kim \& Gray, 2008), corporate governance in the relationship between the parent and its subsidiaries (Filatotchev et al., 2007; Hoskisson, Wright, Filatotchev, \& Peng, 2013), or the effectiveness of parent control through staffing decisions related to management positions in the subsidiary (e.g. Estrin, Baghdasaryan, \& Meyer, 2009; Fang, Jiang, Makino, \& Beamish, 2010).

However, the aspects of capital control per se or staffing decisions are only selected aspects of controlling systems (Nowosielski, 1994), which are part of broader co-ordination strategies in MNEs, critical to ensure the strategic coherence of the functioning of these geographically dispersed entities (Kutschker \& Schmid, 2008). Depending on the level of involvement of foreign capital and the organisation of the MNE, the importance of subsidiary control varies. In order to increase oversight of the subsidiary and to reduce asymmetries in the access to information, parent firms recur to controlling tools (Nilsson, 2002; Granlund, 2003; Moilanen, 2016; Bijlsma-Frankema, 2004). However, the relevance of the controlling system in parent-subsidiary relationships has not received significant attention in the existing studies, both in the disciplines of international controlling (Brenner, 2009; Czyczerski, 2007, 2009; Gigouline, 2001; Hanzlick, 2014; Roth \& Nigh, 1992), as well as broader discipline of international management (Kutschker \& Schmid, 2008; Holtbrügge \& Welge, 2010).

For the purpose of the present literature review, international controlling is defined as a multifunctional management instrument which aims at steering the MNE to optimise its performance, and which is implemented through planning, control, reporting and steering (also see Nowak, 1996). In this respect, accounting can be understood as an instrument providing different decision-makers at different levels with 
multidimensional information required to manage the MNE (Dobija, 2002). In controlling, therefore, the emphasis is to a larger extent shifted to business management than in managerial accounting oriented towards providing managers with information (Brzezin, 1995; Dobija, 2002; Nowosielski, 1994).

\section{Dimensions of International Controlling System}

Assuming that controlling can be understood as a subsystem of business management, emphasis should be placed on aspects related to the management process. The process perspective in business management, as opposed to the static perspective which is geared towards explaining the causes and consequences of specific strategies (Fahey \& Christensen, 1986; Ginsberg \& Venkatraman, 1985; Rajagopalan, Rasheed, \& Datta, 1993), focuses on organisational action that leads to the implementation of a given strategy (Bamberger \& Capallo, 2003). Thus, this perspective focuses on the participants of the process, the methods they use, and the conditions influencing the overall process pattern. When applying the process logic of management to the controlling subsystem, Becker (1990) argues that it consists of instruments, actors, and their tasks.

In a similar vein to Becker (1990), in the context of international controlling Holtbrügge and Welge (2010) draw attention to the important fact that the assessment of the degree of the achievement of objectives should not only take place at the level of the whole company, but also of foreign affiliates. Thus, the goal of controlling in MNEs is not only to ensure the achievement of targets defined at group level, but also at the level of subsidiaries (Hoffjan, 2009). As part of the performance of the evaluation function of international controlling, foreign affiliates can be seen as the area of action of controlling system participants (Pausenberger, 2002). The actions of these participants are related to the coordination function of controlling, which evaluates subsidiary performance ex-post (feedback control), as well as ex-ante (feedforward control). These actions are based on the assumption that acquiring, developing and delivering information related to a subsidiary's operations not only aims to evaluate its performance, but also to influence key managerial decisions of its subsidiaries (Holtbrügge \& Welge, 2010).

Thus, the behavioural function of information delivery through the controlling system is an important control instrument within the MNE. Finally, as a consequence of the existence of the significant environmental and internal complexity of the MNE, there are no clear organisational recommendations that universally respond to the need for coordination in an international context. Thus, a crucial function of the international controlling system pertains to the elaboration of dedicated methods and instruments of planning and control of foreign subsidiaries (Holtbrügge \& Welge, 2010).

To sum up the above considerations, one can notice the acknowledgment of the role of international controlling as a management subsystem of an MNE in extant literature. At the same time, however, there is a notable lack of normative indications regarding the design and implementation of an international controlling system depending on given boundary conditions. While there is evidence in literature on the properties of the controlling system depending on the international strategic orientation of the MNE (Holtbrügge \& Welge, 2010), the type of international holding (Gigouline, 2001), the impact of regulations and accounting standards, as well as the influence of national culture on the approach to accounting (Bednarczyk, 2001), there is a striking lack of theoretically grounded models of the implementation of the controlling system in MNEs. The issue is all the more important that in the area 
of international controlling there is a different understanding of the essence and importance of controlling between different countries, which can have a significant influence on the adoption of controlling solutions in parent-subsidiary relationships.

Figure 1 summarises the basic dimensions of the international controlling system.

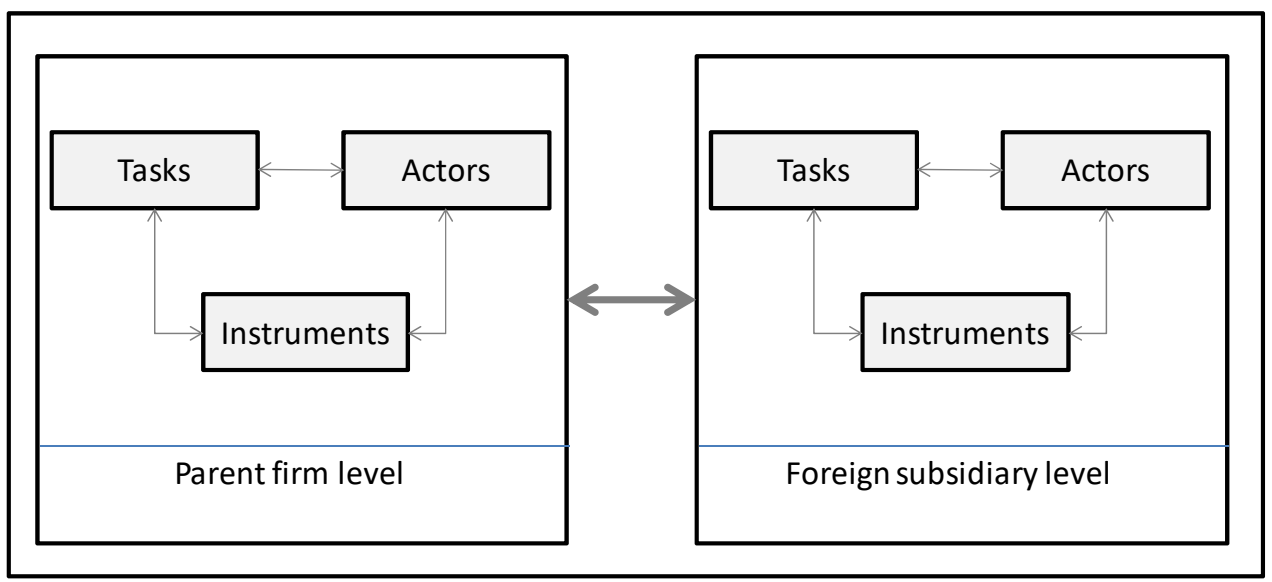

Figure 1. Dimensions of the international controlling system Source: own study.

\section{Gaps in Extant Research}

In extant research on international controlling it is possible to identify research on the formation of a controlling system following mergers and acquisitions (Nilsson, 2002; Bijlsma-Frankema, 2004; Chang, Chang, \& Wang, 2014; Granlund, 2003; Molainen, 2016). When focusing on corporate strategy as a key determinant of controlling systems, attention was paid to the consistency of the strategy of the acquiring and acquired firm (Nilsson, 2002), to a lesser extent focusing on issues such as the cognitive mapping of managers (Bijlsma-Frankema, 2004) or emotions of people involved in shaping the accounting and control systems (Molainen, 2016). This seems to be surprising given that attention was drawn to the importance of the so-called soft factors in the integration of acquired companies (Teerikangas, 2006). In fact, formal controlling systems and the related rules raise emotions of their users and recipients, thereby exerting an influence on their behaviour (Boedker \& Chua, 2013).

And yet, the existing research focused on selected formal elements of management control systems, such as the performance measurement tools and budgeting systems (Granlund, 2003; Nilsson, 2002), ignoring the importance of other significant elements of the controlling system, such as a business management subsystem (Moilanen, 2016). Secondly, in most cases these studies were not rooted in the context of MNEs. According to Czyczerski (2002), controlling in a foreign subsidiary should be tailored to the specific conditions of its operation, as well as its needs and tasks. In the context of MNE controlling, some authors point to the importance of the type of international holding company to the characteristics of the controlling organisation. The type of holding (financial, strategic or operational) that reflects the level of integration of a subsidiary within the MNE translates into the budgeting and performance measurement system, incentive and remuneration 
system (Gigouline, 2001). In addition, it influences the power of direct involvement of the controlling unit in the affairs of the subsidiary and the areas that it is specifically interested in. However, the structure of an international capital group is but one of many variables influencing the controlling system of a subsidiary. Thus, Merchant and Van Der Stede (2007) distinguish further important variables:

- factors related to the company itself (such as organisation, strategy, financial resources, organisational culture of the company);

- the country of the investment country (such as local business environment, political risk, economic risk);

- other holding related factors (such as budgeting system, performance measurement system, type and intensity of control used, organisational culture, etc.).

Moreover, Holtbrügge and Welge (2010), do draw attention to the fact that the international strategy pursued by the company, which includes, inter alia, the role and importance of foreign subsidiaries in the operations of the MNE, has an influence on the objectives of controlling and locating key decision makers in the field of controlling, the standardisation of controlling instruments, criteria for assessing performance, or the direction and scope of information flows within the controlling system.

However, while in the existing literature on international controlling there may be some limited awareness of the existence of multi-level determinants shaping the controlling system of a foreign subsidiary, there is virtually no systematic and normative approach to describing interdependencies between these determinants (Czyczerski, 2009; Holtbrügge \& Welge, 2010).

\section{INSTITUTIONAL DETERMINANTS OF FOREIGN SUBSIDIARY CONTROLLING}

\section{Applications of Institutional Theory in International Business Research}

Due to the strong dependence of the activity of MNEs (especially in international accounting aspects) on regulatory conditions and differences in business environments across countries, the institutional theory seems to be a promising analytical approach. 'Institutions are the rules of the game in a society or, more formally, are the humanly devised constraints that shape human interaction' (North, 2011, p. 3). In other words, institutions provide a framework that limits uncertainty by setting the limits of choices made by individuals. According to Scott (1995, p. 33), institutions provide 'regulative, normative, and cognitive structures and activities that provide stability and meaning to social behaviour'. Peng et al. (2009) emphasise that management teams exercise their interests in a rational manner and make choices within a specific institutional framework. On the other hand, Oliver (1997) discusses the concept of normative rationality advocated by institutional theorists. Unlike economic rationality, where managers make rational choices limited by uncertainty, information deficiency, or imperfections of cognition, normative rationality implies that managers behave in an irrational manner, limited by social judgment, normative context of decisions, and inertia resulting from habits. While economic rationality, albeit subject to constraints, aims at maximising productivity and profitability, normative rationality refers to decisions taken in the context of norms, values and traditions in the firm and its environment, which maximise legitimacy, thus leading to a suboptimal resource allocation. 
Institutional frameworks can be broadly divided into formal and informal (North, 1991, p. 97). Formal restrictions include rules set in the policy area (e.g. laws, resolutions, ordinances, etc.), legal decisions (e.g. court decisions) or contracts concluded between business entities. Informal institutions include socially sanctioned behavioural standards rooted in culture, ethics, and ideology. North (2011, p. 4) suggests that in situations where formal institutions fail, informal institutions help to reduce uncertainty and set a benchmark for organisations to shape their behaviour.

The analysis of formal and informal institutions in the functioning of MNEs has become of particular importance in recent years, given the growing awareness of their impact on business operations and their economic performance (Dunning \& Lundan, 2008). Researchers in the area of new institutional economics have focused on the impact of institutional environment on decisions such as FDI modes (Estrin, Baghdasaryan \& Meyer, 2009; Yiu \& Makino, 2002), decisions on FDI location (Globerman \& Shapiro, 2008), or the impact on firm performance (Brouthers, Brouthers, \& Werner, 2008).

On the other hand, another strand of management research based on the sociological part of institutional theory is devoted to the demonstration of legitimacy by companies. This manifests itself in the adaptation of organisational structures, processes and strategies that allow them to cope with expectations raised by both the external and internal environment (Walgenbach, 1995). The process of institutionalisation leads to the elimination of behaviour that does not conform to the norms considered to be legitimate, resulting in the uniformity of corporate strategy within the same institutional environment (Oliver, 1991). Di Maggio and Powell (1983) state that this isomorphism is related to political, formal and informal pressures (coercive isomorphism), the adoption of standards that limit uncertainty (mimetic isomorphism), and the professionalism of management in organisations (normative isomorphism).

The application of this line of reasoning to MNE operations has highlighted the process by which subsidiaries gain legitimacy from the perspective of both the host country and the parent company (Kostova \& Zaheer, 1999), entry modes (e.g. Xu \& Shenkar, 2002), or staffing expatriates vs. local managers (Xu, Pan, \& Beamish, 2004). The overarching premise of this logic is to reduce the costs of doing business by gaining legitimacy in the formal and informal institutional environment of the foreign country (Zaheer \& Mosakowski, 1997).

\section{Institutions Affecting International Controlling}

Based on the above review, it can be stated that the impact of institutional pressures on the controlling system in MNEs has remained poorly understood. This is surprising since controlling in MNEs is one of the areas where the broadly defined institutions can exert a significant influence. In fact, future research should take into account to a larger extent the various formal institutions that can influence the shape of the controlling system in an MNE, such as:

- structure of the MNE in general;

- applicable accounting standards, including both international (e.g. International Accounting Standards and International Financial Reporting Standards), as well as local legal acts (e.g. accounting laws, national accounting standards);

- corporate governance;

- tax regulations (including laws on tax regulations in Poland, as well as international agreements and conventions ratified by Poland); 
- transfer pricing - relying on the domestic legal regulations, mainly in the Corporate Income Tax Act, as well as in the Tax Code and the Ordinance of the Minister of Finance, international guidelines and reports, OECD guidelines and reports.

Informal institutions shaping different dimensions of the controlling system in a foreign subsidiary include:

- organisational culture (parent and subsidiary level);

- the culture of the country of origin of managers shaping and implementing the control system, as well as being the subject of controlling;

- awareness of the concept of controlling and the need for its implementation;

- values and rules in companies.

Despite the fact that the influence of this former category of institutions on the design of the controlling system seems to be intuitive and straightforward, the less obvious fact is the interdependence of the formal institutions of the parent firm, the country of the subsidiary and the MNE itself, on the final shape of the controlling system in the foreign subsidiary.

In addition, the role of informal institutions as a determinant of the controlling system also remains an area of scarce research, requiring further qualitative research to better understand the interdependencies between the different categories of institutions. Third, mutual interactions between formal and informal institutional forces, especially when weak formal institutions are present, are also important issues from the point of view of both the institutional theory itself and the practice of MNE controlling.

The analysis of these issues is also relevant in a broader sense than controlling in MNEs sensu stricto, because it actually coincides with a number of limitations of the existing research on international corporations. From the research perspective on mergers and acquisitions (M\&A), one can observe the concentration of research on the process of integration of entities (especially with regard to the challenges of cultural differences at the level of countries and corporations), the impact of the incorporation of new subsidiaries into the group firm value and performance. On the other hand, less attention has been paid to the changes taking place in controlling and management efficiency, particularly at the level of a foreign subsidiary. While controlling in MNEs is a thoroughly practical issue that requires an orientation towards its managerial implications, this goal can only be achieved by adopting a solid theoretical foundation to provide a logical analytical framework, whereby the institutional approach discussed above appears to be a promising path.

\section{Towards a Conceptual Framework}

The analytical framework (Figure 3) developed based on the discussion presented in the preceding sections, future research could focus on empirical analysis of subsidiaries operating within international capital groups in order not only to empirically develop concepts developed in the literature review, but particularly to deepen the understanding of interactions between internal and external, formal and informal institutions in shaping the controlling system of the foreign subsidiary. The formalisation of some initial expectations related to these interdependencies can constitute the first step towards the formulation of a unique model of implementation of the controlling system in a subsidiary within the MNE. According to the aforesaid understanding of the controlling system, future analyses should particularly cover the following aspects: 


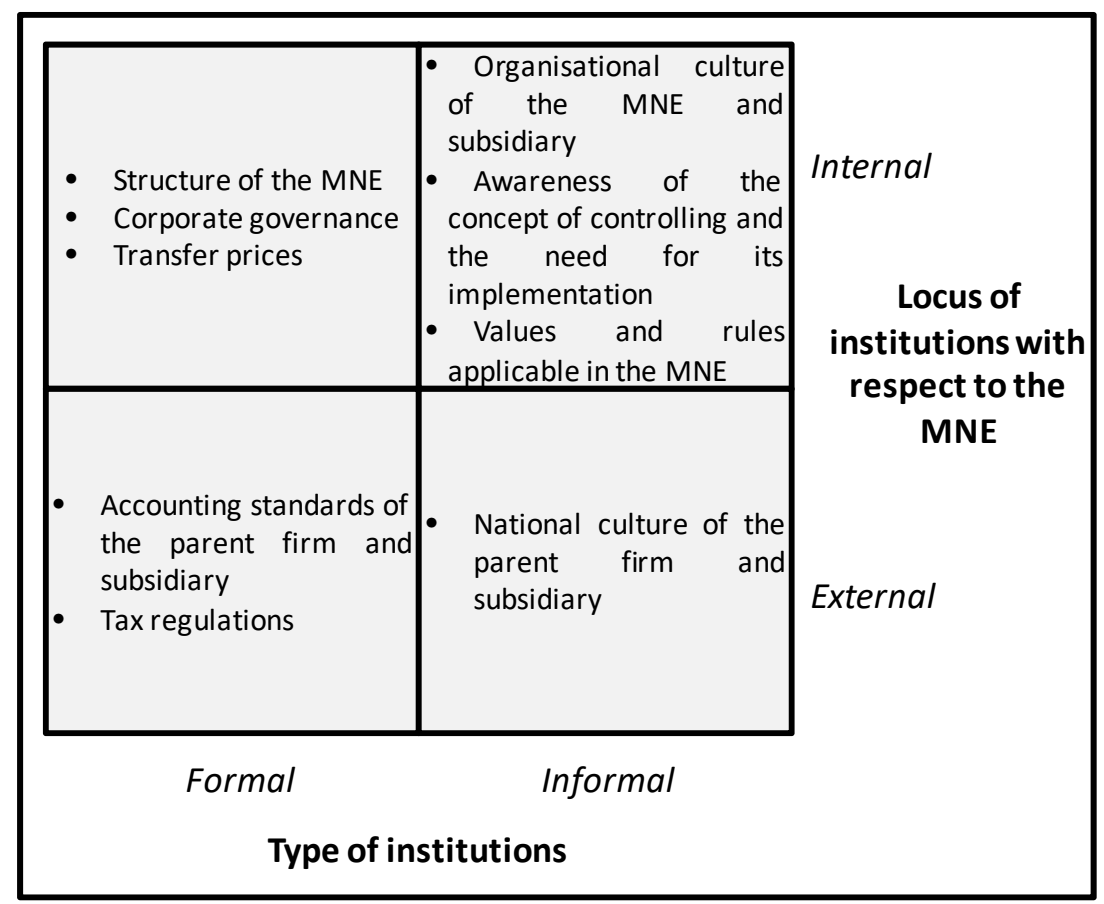

Figure 2. Typology of institutions determining the implementation of the controlling system in an MNE Source: own study.

- tasks (particularly controlling intensity, division of tasks and roles between the headquarters and the subsidiary and its evolution, the scope of the formalisation of tasks by the parent company);

- actors (particularly the formal and informal setting up of employees responsible for controlling, their scope of autonomy, the intensity of the cooperation with the parent firm);

- instruments (particularly the selection and adaptation of horizontal control tools, e.g. central and decentralised transfer pricing, the scope of supporting control tools such as standards, profiles, frameworks, global and local projects, selection and adaptation, as well as the evolution of the performance measurement system as a vertical control tool).

The understanding of external and internal institutional pressures affecting the controlling system within the parent-subsidiary relationship, as well as their changes over time can lead to the development of an implementation model with relevance for both theorists and practitioners of international management. In fact, it will suggest which types of solutions related to the controlling system are acceptable and most efficient given the presence of given boundary conditions. As a preliminary effort in the construction of such a model, a group of working propositions has been formulated to inspire further research in this area: 


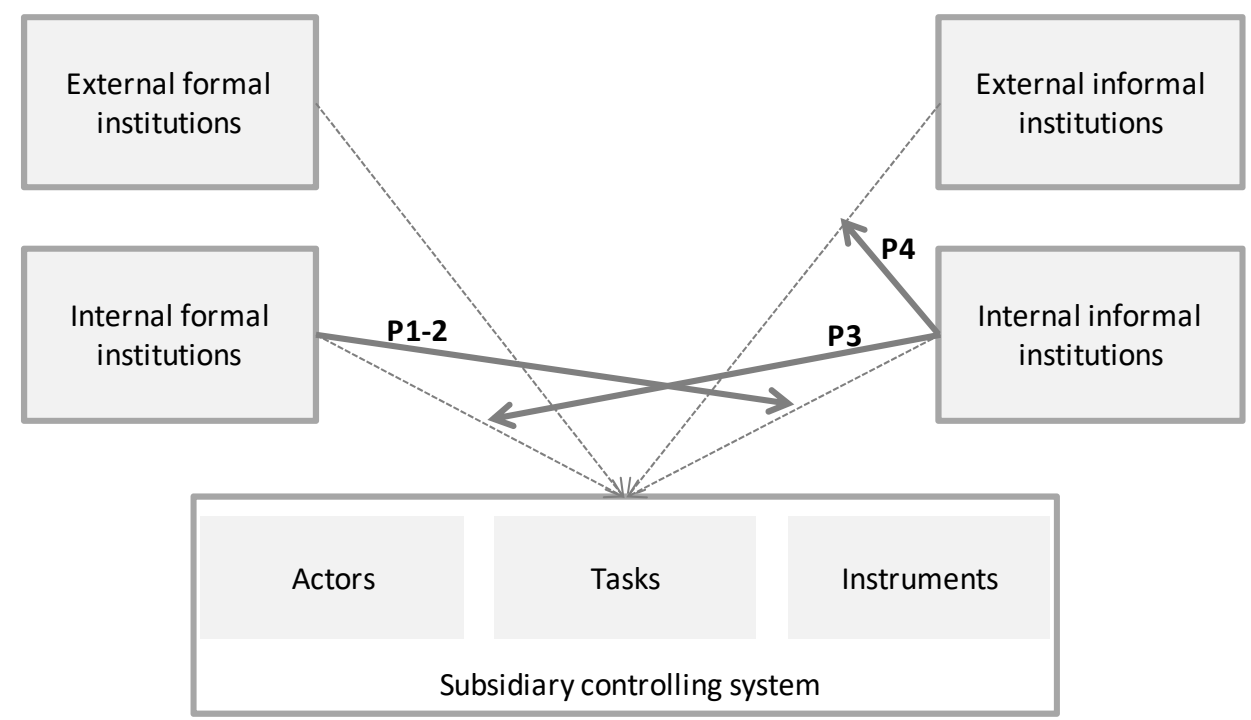

Figure 3. Analytical framework of the influence of institutions on the implementation of the controlling system of a subsidiary in an MNE

Source: own study.

Proposition 1: The definition of tasks in the controlling system of a subsidiary is to the largest extent influenced by informal internal institutions, whereby the importance of institutions at the level of the parent firm as compared to those at the level of the subsidiary is dependent on formal internal institutions.

Proposition 2: The definition of the type and role of actors in the controlling system of a subsidiary is to the largest extent influenced by informal internal institutions, whereby the importance of institutions at the level of the parent firm as compared to those at the level of the subsidiary is dependent on formal internal institutions.

Proposition 3: The definition of instruments in the controlling system of a subsidiary is to the largest extent influenced by formal internal institutions, whereby the importance of institutions at the level of the parent firm as compared to those at the level of the subsidiary is dependent on informal internal institutions.

Proposition 4: In the case of contradictory pressures from external informal institutions of the country of the parent firm and of the subsidiary, their impact on the subsidiary's controlling system depends on informal internal institutions.

\section{CONCLUSIONS}

Despite the growing importance of controlling in economic sciences and in business reality, there are still controversies as to what should be understood under this concept (Kochalski, 2012). Empirical research also shows that companies in countries with shorter market traditions, such as the CEE region including Poland, still do not fully utilise the control tools, and new solutions are being implemented slowly (Dobroszek, 2011). In each country, controlling developed in a different way and had a different meaning in practice. Little attention has 
been paid to the in-depth investigation of the specific conditions of the control systems apart from commonly known considerations of specific legal requirements or the structure of the capital group itself, as well as their interrelationships, and the implications of these choices in view of the effectiveness of the controlling system. Moreover, predominant attention in research on management control has been devoted to the structural and formal aspects of controlling systems, while neglecting the process-related and personal aspects of controlling, which the present conceptual paper is accentuating.

The controlling system provides a spectrum of tools to effectively support the business objectives of a given organisational unit (Foremna-Pilarska, 2007). These tools are very diverse, ranging from liquidity indicators, to very elaborate measures, covering almost the entire organisation, such as the balanced scorecard (Chomuszko, 2015). Based on the literature of the subject, it can be seen that the selection of tools used by the controlling system depends on several factors, including the objectives and tasks of the controlling system, the type of controlling, internal and external conditions (Marciniak, 2004). These considerations, however, have mostly focused on the national context, without taking into account the challenges posed by designing controlling systems in MNEs operating in different types of institutional environments, therefore exposed to greater institutional complexity. Moreover, the analysis of controlling systems has often been treated as an autonomous subject of interest and thus explored in isolation, while ignoring the broader context of corporate strategy, in particular in the context of firms operating internationally.

As stated above, institutional aspects can have a significant impact on the functioning of MNEs in relation to shaping their controlling systems. Informal institutions (including cultural factors) can influence the formation of the controlling system in the relations between the subsidiaries of the MNE, whereby not only institutions within the environment of the country of the parent and the country of the subsidiary (which is the most common understanding of the institutional environment) should be taken into account, but also those within the MNE itself. This same distinction pertains to formal institutions, whereby internal institutions are related to the MNE structure and corporate governance. An important research deficit in this area is the interrelation between the aforementioned institutional pressures, which may be complementary or substitutive, and, on the other hand, either operate in a similar way in affecting the controlling system of a subsidiary, or create contradictions. Based on the general indications of institutional theory and their novel application to controlling in MNEs, a useful reference point for future empirical research is provided herewith. Conducting in-depth qualitative research will allow for a set of recommendations that are relevant to managers responsible for the effective implementation of management control systems, both at the level of headquarters and that of the subsidiary with an MNE. The conceptual framework proposed in this paper can be regarded as a possible first step towards further empirical investigations. 


\section{REFERENCES}

Bamberger, I., \& Cappallo, S. (2003). Problembereiche und Ansätze der Strategischen Prozessforschung. In M. J. Ringlstetter, H. Henzler \& M. Mirow (Eds.), Perspektiven der Strategischen Unternehmensführung (pp. 93-120). Wiesbaden: Gabler.

Beamish, P.W., \& Lee, C. (2003). The Characteristics and Performance of Affiliates of Small and Medium-Size Multinational Enterprises in an Emerging Market. Journal of International Entrepreneurship, 1, 121-134.

Becker, W. (1990). Funktionsprinzipien des Controlling. ZfB, 3, 295-318.

Bednarczyk, M. (2001). Organizacje publiczne: zarzqdzanie konkurencyjnościq. Warszawa: Wydawnictwo Naukowe PWN.

Bijlsma-Frankema, K. (2004). Dilemmas of managerial control in post-acquisition processes. Journal of Managerial Psychology, 19(3), 252-268.

Boedker, C., \& Chua, W.F. (2013). Accounting as an affective technology: A study of circulation, agency and entrancement. Accounting, Organizations and Society, 38(4), 245-267.

Brenner, B. (2009). Management control in Central and Eastern European subsidiaries. Houndmills: Palgrave Macmillan.

Brouthers, K.D., Brouthers, L.E., \& Werner, S. (2008). Resource-Based Advantages in an International Context?. Journal of Management, 34, 189-217.

Brzezin, W. (1995). Ogólna teoria rachunkowości. Częstochowa: Wydawnictwo Politechniki Częstochowskiej.

Canabal, A., \& White, G.O. (2008). Entry Mode Research: Past and Future. International Business Review, 17(3), 267-284.

Chang, S.I., Chang, I.C., \& Wang, T. (2014). Information systems integration after merger and acquisition. Industrial Management \& Data Systems, 114(1), 37-52.

Chomuszko, M. (2015). Controlling procesów: jak wdrożyć. Warszawa: Wydawnictwo Naukowe PWN.

Corbin, J., \& Strauss, A.L. (2008). Basics of Qualitative Research: Techniques and Procedures for Developing Grounded Theory. Thousand Oaks: Sage.

Czinkota, M.R., Ronkainen, I.A., \& Moffett, M.H., (2005). International Business (7th ed.). Mason: South-Western.

Czyczerski, M. (2002). Controlling finansowy w jednostce zależnej kapitałowo na przykładzie przedsiębiorstwa działającego w branży motoryzacyjnej. Prace Naukowe Akademii Ekonomicznej we Wrocławiu, 948, 37-43.

Czyczerski, M. (2007). Międzynarodowe aspekty controllingu w spółkach zależnych. Prace Naukowe Akademii Ekonomicznej we Wrocławiu, 1175, 72-79.

Czyczerski, M. (2009). Uwarunkowania funkcjonowania controllingu spółek zależnych. Prace Naukowe Uniwersytetu Ekonomicznego we Wrocławiu, 58, 62-66.

Daniels, J.D., \& Radebaugh, L.H. (2007). International Business. Environments and Operations. (11th ed.). Upper Saddle River: Prentice-Hall.

DiMaggio, P., \& Powell, W. (1983). The Iron Cage Revisited: Institutional Isomorphism and Collective Rationality in Organizational Fields, American Sociological Review, 48, 286-304.

Dobija, M. (2002). Rachunkowość zarzqddcza i controlling. Warszawa: Wydawnictwo Naukowe PWN.

Dobroszek, J. (2011). Ewolucja controllingu w praktyce amerykańskich i europejskich przedsiębiorstw. Acta Universitatis Lodziensis. Folia Oeconomica, 249. 
Dunning, J.H., \& Lundan, S.M. (2008). Institutions and the OLI Paradigm of the Multinational Enterprise. Asia Pacific Journal of Management, 25(4), 573-593.

Eisenhardt, K.M. (1989). Building Theories from Case Study Research. The Academy of Management Review, 14(4), 532-550.

Estrin, S., Baghdasaryan, D., \& Meyer, K. (2009). The Impact of Institutional and Human Resource Distance on International Entry Strategies. Journal Of Management Studies, 46(7), 1171-1196.

Fahey, L., \& Christensen, H.K. (1986). Evaluating the Research on Strategy Content. Journal of Management, 12(2), 167-183.

Fang, Y., Jiang, G.J., Makino, S., \& Beamish, P.W. (2010). Multinational Firm Knowledge, Use of Expatriates, and Foreign Subsidiary Performance. Journal of Management Studies, 47(1), 27-54.

Filatotchev, I., Strange, R., Piesse, J., \& Lien, Y. (2007). FDI by Firms from Newly Industrialised Economies in Emerging Markets: Corporate Governance, Entry Mode and Location. Journal of International Business Studies, 38(4), 556-572.

Filatotchev, I., Jackson, G., \& Nakajima, C. (2013). Corporate governance and national institutions: A review and emerging research agenda. Asia Pacific Journal of Management, 30(4), 965-986.

Foremna-Pilarska, M. (2007). Teoretyczne problemy controllingu-definicja. Prace Naukowe Akademii Ekonomicznej we Wrocławiu, 1174, 154-162.

Gaur, A.S., \& Lu, J.W. (2007). Ownership Strategies and Survival of Foreign Subsidiaries: Impacts of Institutional Distance and Experience. Journal of Management, 33(1), 84-110.

Gigouline, I. (2001). Ansatzpunkt zur Gestaltung des Beteiligungscontrollings von Tochterunternehmen westlicher Konzerne in osteuropaischen Landern. Monachium: Hererbert Utz Verlag.

Ginsberg, A., \& Venkatraman, N. (1985). Contingency Perspectives of Organizational Strategy: A Critical Review of the Empirical Research. Academy of Management Journal, 10(3), 421-434.

Globerman, S., \& Shapiro, D.M. (2008). Outward FDI and the Economic Performance of Emerging Markets. In K.P Sauvant (Ed.), The Rise of Transnational Corporations from Emerging Markets. Threat or Opportunity? (pp. 229-271). Cheltenham: Edward Elgar.

Granlund, M. (2003). Management accounting system integration in corporate mergers: a case study. Accounting, Auditing \& Accountability Journal, 16(2), 208-243.

Hahn, D., \& Hungenberg, H. (2001). PuK-Wertorientierte Controllingkonzepte (6th ed.). Wiesbaden: Gabler.

Hanzlick, M. (2014). Management control systems and cross-cultural research: Empirical evidence on performance measurement, performance evaluation and rewards in a cross-cultural comparison. BoD-Books on Demand.

Hoffjan, A. (2009). Internationales controlling. Stuttgart: Schäffer-Poeschel.

Holtbrügge, D., \& Welge, M. (2010). Internationales Management, Theorien, Funktionen, Fallstudien (5th ed.). Stuttgart: Schäffer-Poeschel Verlag für Wirtschaft.

Horváth, P. (2009). Controlling (11th. ed.). Monachium: Vahlen.

Hoskisson, R.E., Wright, M., Filatotchev, I., \& Peng, M.W. (2013). Emerging Multinationals from MidRange Economies: The Influence of Institutions and Factor Markets. Journal of Management Studies, 50(7), 1295-1321.

Jędralska, K. (2003). Controlling w zarządzaniu przedsiębiorstwem międzynarodowym. Prace Naukowe, Katowice: Akademia Ekonomiczna w Katowicach.

Kim, Y., \& Gray, S.J. (2008). The Impact of Entry Mode Choice on Foreign Affiliate Performance: The Case of Foreign MNEs in South Korea. Management International Review, 48(2), 165-188.

Kochalski, C. (2012). Analiza finansowa i controlling w przedsiębiorstwie. Powrót do rozważań. Zeszyty Naukowe Uniwersytetu Szczecińskiego. Finanse. Rynki finansowe. Ubezpieczenia, (56), 83-93. 
Kostova, T., \& Zaheer, S. (1999). Organizational Legitimacy Under Conditions of Complexity: The Case of the Multinational Enterprise. Academy of Management Review, 24(3), 64-81.

Kutschker, M., \& Schmid, S. (2008). Internationales Management. München: Oldenbourg.

Marciniak, S. (2004). Controlling: filozofia, projektowanie. Warszawa: Difin.

Marciniak, S. (2008). Controlling: teoria, zastosowania. Warszawa: Difin.

Merchant, K.A., \& Van der Stede, W.A. (2007). Management control systems: performance measurement, evaluation and incentives. Upper Saddle River, USA: Pearson Education.

Miles, M.B., \& Huberman, A.M. (2000). Analiza danych jakościowych. Białystok: Trans Humana.

Moilanen, S. (2016). Sensemaking of post-acquisition changes in accounting and control. Journal of Applied Accounting Research, 17(1), 24-42.

Neely, A. (2005). The evolution of performance measurement research: developments in the last decade and a research agenda for the next. International Journal of Operations \& Production Management, 25(12), 1264-1277.

Neely, A., Gregory, M., \& Platts, K. (1995). Performance measurement system design: a literature review and research agenda. International Journal of Operations \& Production Management, 15(4), 80-116.

Neely, A., Gregory, M., \& Platts, K. (2005). Performance measurement system design: A literature review and research agenda. International Journal of Operations \& Production Management, 25(12), 1228-1263.

Nesterak, J., \& Kluwer, W.W.W. (2015). Controlling zarzqdczy: projektowanie i wdrażanie. Warszawa: Wolters Kluwer.

Nesterak, J. (2015). Ewolucja controllingu w Polsce i na świecie. Zeszyty Naukowe Uniwersytetu Ekonomicznego w Krakowie, 905, 37-54.

Nilsson, F. (2002). Strategy and management control systems: a study of the design and use of management control systems following takeover. Accounting \& Finance, 42(1), 41-71.

North, D.C. (1991). Institutions. The Journal of Economic Perspectives, 5(1), 97-112.

North, D.C. (2011). Institutions, Institutional Change and Economic Performance. Cambridge: Cambridge University Press.

Nowosielski, S. (1994). Podstawy kontrolingu w zarzqdzaniu produkcjq. Wrocław: Wydawnictwo Akademii Ekonomicznej im. Oskara Langego.

OECD (2008). OECD Guidelines for Multinational Enterprises, Geneva: OECD Publishing.

Oliver, C. (1991). Strategic Responses to Institutional Processes. The Academy of Management Review, 16(1), 145-179.

Oliver, C. (1997). Sustainable Competitive Advantage: Combining Institutional and Resource-based Views, Strategic Management Journal, 18(9), 697-713.

Pausenberger, E. (2002). Ansätze zur situationsgerechten Erfolgsbeurteiliung von Auslandsgesellschaften. In K. Macharzina \& M.J. Oesterle (Eds.), Handbuch Internationales Managemement (2nd ed., pp. 1163-1175). Wiesbaden: Gabler.

Peng, M.W., Sun, S.L., Pinkham, B., \& Chen, H. (2009). The Institution-based View as a Third Leg for a Strategy Tripod. Academy of Management Perspectives, 23(3), 63-81.

Preissler, P.R. (1992). Controlling: Lehrbuch und Intensivkurs. Munchen - Wien: Oldenbourg Verlag.

Rajagopalan, N., Rasheed, A., \& Datta, D. (1993). Strategic Decision Processes: Critical Review and Future Directions. Journal of Management, 19(2), 349-384 
Roth, K., \& Nigh, D. (1992). The Effectiveness of Headquarters-Subsidiary Relationships: The Role of Coordination, Control, and Conflict. Journal of Business Research, 25(4), 277-301.

Scott, W.R. (1995). Institutions and Organizations. Thousand Oaks: Sage.

Seuring, S., \& Gold, S. (2012). Conducting Content-analysis Based Literature Reviews in Supply Chain Management. Supply Chain Management: An International Journal, 17(5), 544-555.

Teerikangas, S. (2006). Silent forces in cross-border acquisitions: an integrative perspective on postacquisition integration. Helsinki: University of Technology.

Verbeke, A., Li, L., \& Goerzen, A. (2009). Toward More Effective Research on the MultinationalityPerformance Relationship. Management International Review, 49, 149-162.

Vernon, R., Wells, L.T., \& Rangan, S. (1996). The Manager in the International Economy. (7th. ed.). London: Prentice Hall.

Vollmuth, H.J. (2000). Controlling: planowanie, kontrola, kierowanie: podstawy budowy systemu controllingu. Warszawa: Placet.

Walgenbach, P. (1995). Die Theorie der Strukturierung. Die Betriebswirtschaft, 55(6), 761-782.

Xu, D., Pan, Y., \& Beamish, P.W. (2004). The Effect of Regulative and Normative Distances on MNE Ownership and Expatriate Strategies. Management International Review, 44(3), 285-307.

Xu, D., \& Shenkar, O. (2002). Institutional Distance and the Multinational Enterprise. Academy of Management Review, 27(4), 608-618.

Yadav, N., \& Sagar, M. (2013). Performance measurement and management frameworks: Research trends of the last two decades. Business Process Management Journal, 19(6), 947-971.

Yiu, D., \& Makino, S. (2002). The Choice Between Joint Venture and Wholly Owned Subsidiary: An Institutional Perspective. Organization Science, 13(6), 667-683.

Zaheer, S., \& Mosakowski, E. (1997). The Dynamics of the Liability of Foreignness: A Global Study of Survival in Financial Services. Strategic Management Journal, 18(6), 439-464. 


\section{Authors}

The contribution share of authors amounts to

$30 \%$ for Cezary Kochalski and 70\% for Magdalena Łuczak-Trąpczyńska.

\section{Cezary Kochalski}

Cezary Kochalski, PhD and post-doctoral degree in economic sciences is associate professor at the Poznań University of Economics and Business and head of the Department of Controlling, Financial Analysis and Valuation. Graduate of the Poznań University of Economics and Business, he also completed his postgraduate studies at the University of Stirling (UK) in accounting and finance. He has been a member of the Examination Commission for candidates for Certified Public Accountants since 2013. He acquired his experience in business inter alia as a financial analyst at the Wielkopolski Bank Kredytowy, advisor to the President of the Polish National Bank, vice-rector responsible for strategy and development at the Poznań University of Economics, and advisor to the Mayor of Poznań, responsible for strategy. He is an author of over 100 publications on economic analysis, financial analysis, controlling, strategic management, management accounting and value management.

Correspondence to: Prof. UEP, dr hab. Cezary Kochalski, Department of Controling, Fianncial Analysis and Valuation, Faculty of Management, Poznań University of Economics and Business, al. Niepodległości 10, 61-875 Poznań, Poland, e-mail: c.kochalski@ue.poznan.pl

\section{Magdalena Łuczak-Trąpczyńska}

Magdalena Łuczak-Trąpczyńska, M.Sc. in Management of the Poznań University of Economics and Business, is an external doctoral candidate at the Department of Controlling, Financial Analysis and Valuation. Her doctoral research concentrates on the institutional determinants of the controlling system in MNE subsidiaries. She is chief financial officer in a subsidiary of an international capital group operating in Poland, and served as board member in the same company. Overall, she has extensive managerial experience in controlling positions in both headquarters and subsidiaries of MNEs, where she overlooked the implementation and optimisation of controlling systems and was involved in a number of cross-border projects.

Correspondence to: Mgr Magdalena Łuczak-Trąpczyńska, PhD Student, Faculty of Management, Poznań University of Economics and Business, al. Niepodległości 10, 61-875 Poznań, Poland, email: trapczynska.magdalena@gmail.com

\section{Copyright and License}

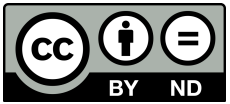

This article is published under the terms of the Creative Commons Attribution - NoDerivs (CC BY- ND 4.0) License

http://creativecommons.org/licenses/by-nd/4.0/

Published by the Centre for Strategic and International Entrepreneurship - Krakow, Poland 